\title{
Environmental factors and asthma and allergy in schoolchildren from Western Australia
}

\author{
L.J. Palmer*,+, I.J. Valinsky*, T. Pikora*, S.R. Zubrick ${ }^{\S}$, L.I. Landau*
}

Environmental factors and asthma and allergy in schoolchildren from Western Australia. L.J. Palmer, I.J. Valinsky, T. Pikora, S.R. Zubrick, L.I. Landau. (C)ERS Journal Ltd 1999. ABSTRACT: The association of environmental factors with atopic disease in children remains poorly understood. The aim of this study was to investigate the relatio nship between socio-environmental factors and symptoms of asthma and atopy in 6-7-yr-old children assessed as an adjunct to Phase I of the International Study of Asthma and Allergy in Childhood in Perth, Western Australia.

Parental questionnaire responses were obtained for 2,193 children $(73.6 \%)$ in 34 randomly selected primary schools in the Perth metropolitan area.

Children born in Australia had a significantly increased risk of current asthma (odds ratio (OR) 237, $p=0.001$ ). Having a mother born in Australia was the only factor independently associated with an increased risk of current hay fever (OR 1.56, $p=0.005$ ). Increasing numbers of people living in the home were significantly associated with a multiplicative decrease in risk of current asthma $(\mathrm{OR} 0.88, p=0.03)$ and eczema (OR 0.82, $\mathrm{p}=\mathbf{0 . 0 1})$. Houses made of fibrocement $(\mathrm{OR} 2.40, \mathrm{p}=\mathbf{0 . 0 2})$ and the presence of mats on less than half of the floor area in the "main bedroom" (relative to wall-to-wall carpet) (OR 3.50, $p=0.003)$ were associated with an increased risk of current eczema. All reported associations were independent of socioeconomic status (categorized by school), age and sex.

This study suggests that household and country-specific environmental factors are associated with asthma, hay fever and eczema risk in 6-7-yr-old schoolchildren, and may have substantially contributed to the increased prevalence of these diseases in Australia.

Eur Respir J 1999; 14: 1351-1357.

\begin{abstract}
*Dept of Paediatrics, University of Western Australia, Perth, Australia, 6907. ${ }^{+}$Division of Biostatistics and Genetic Epidemiology, TVW Telethon Institute for Child Health Research, Perth, Australia, 6872. ${ }^{5}$ Division of Psychosocial Research, TVW Telethon Institute for Child Health Research, Perth, Australia, 6872.
\end{abstract}

Correspondence: L. Palmer, University Dept of Paediatrics, Princess Margaret Hospital for Children, GPO Box D184, Perth, Australia 6001, Fax: 61893882097

Keywords: Asthma, childhood, eczema, epidemiology, International Study of Asthma and Allergy in Childhood, rhinitis

Received: March 71999

Accepted after revision August 61999

This study was supported by the Asthma Foundation of Western Australia. L.J. Palmer is a National Health \& Medical Research Council of Australia Public Health Postdoctoral Fellow.
Atopy is a familial syndrome including asthma, hay fever (atopic rhinitis) and eczema (atopic dermatitis), and is characterized by elevated serum immunoglobulin E levels $[1,2]$. Clinical symptoms of atopy are very common in the developed world; most surveys have indicated a population prevalence of $\sim 20-30 \%$ with a peak of $40-50 \%$ in young adolescents [3-5].

Asthma is the single most common chronic childhood disease in developed nations [5,6]. Similar to other developed nations, asthma is common in Australia, and is a major public health problem, affecting $>20 \%$ of the paediatric population and $5-10 \%$ of adults $[5,7,8]$. In addition to significant childhood morbidity, asthma, eczema and hayfever carry very substantial direct and indirect economic costs $[8,9]$. There is concern because the prevalence of childhood asthma, hay fever and eczema appear to be increasing in many nations $[10,11]$.

The International Study of Asthma and Allergy in Childhood (ISAAC) is a multinational collaborative project developed to investigate variations in childhood asthma and allergy at the population level [12]. Data collection and analysis for Phase 1 of ISAAC has been completed in Perth, Western Australia. Phase 1 was designed to use core questionnaires to assess the prevalence and severity of asthma and other allergic disease in defined populations [12].

There is consistent evidence that environmental factors acting during early childhood play a key role in the pa- thogenesis of atopic disease $[13,14]$, and it is likely that atopic symptoms reflect the action of environmental trigger factors in genetically susceptible individuals [15]. The increasing prevalence of asthma in the developed world has generally been accompanied by increasing prevalence of other atopic diseases and sensitization to common aeroallergens $[10,11]$. These changes have been too rapid to be accounted for by changes in gene frequencies. It is also unlikely that they can be fully accounted for by changes in either clinical diagnostic patterns or increased recognition of atopy symptoms by the general population $[16,17]$. These changes in prevalence suggest altered environmental factors are mediating substantial increases in the prevalence of atopic diseases from early in life.

Because of the clinical, social and economic importance of childhood asthma and other atopic disease [18], environmental factors which might be targeted in preventive measures are being sought as a matter of some urgency in Australia and other nations. Socioenvironmental factors previously found to be associated with symptoms of atopic disease have included country-specific effects such as country of birth [19] and household-specific effects such as family size [20]. The various socioenvironmental factors important in determining risk of atopic disease in Perth children of school age are poorly defined.

The primary aim of this study was, therefore, to investigate the relationship between symptoms of atopic disease 
(asthma, hay fever and eczema) and selected environmental factors in a population-based sample of 6-7-yr-old Western Australian schoolchildren.

\section{Methods}

The population of Western Australia is concentrated in the Perth metropolitan area, which has a population of approximately 1.4 million. Perth has a Mediterranean climate with hot dry summers and mild wet winters.

The names of all public and private primary schools in the Perth metropolitan area were first obtained from the Education Department of the Government of Western Australia. Primary schools were then randomly chosen from this list (i.e. cluster sampling). ISAAC phase 1 questionnaires [12] were handed out at school to 2,979 children aged 6-7 yrs in 34 primary schools. Data collection took place in March and June 1995. Parents completed the core ISAAC questionnaire and an additional questionnaire regarding housing factors.

All data collection activities were approved by the Ethics Committees of the University of Western Australia and the Princess Margaret Hospital for Children. Consent was obtained from the schools and parents of all subjects participating.

\section{Parameters assessed}

Symptoms and disease status in the preceding 12 months were assessed from the core ISAAC questionnaires. Asthma, hay fever and eczema in the last 12 months were defined as positive responses to selected questions (see Appendix).

The demographic data assessed included school attended; sex; date of birth; country of birth of child, and country of birth of mother.

The additional data collected regarding housing were: type of home; building material; floor construction; age of home, number of bedrooms; number of people usually living in the home; and type of floor covering in each room of the house.

A binary categorization (disadvantaged/not disadvantaged) reflecting the mean socioeconomic status (SES) of the pupils was recently developed to identify disadvantaged schools in the state and private sectors as part of the Western Australian Child Health Survey [21]. These data were available for 28 of the schools included in this study. All children attending a school were assigned the binary SES categorization of that school. Data were not available for six schools which were not sampled by the Western Australian Child Health Survey (itself a random sample of all Perth metropolitan primary schools); the proportion of private and state schools amongst the missing six schools were identical.

\section{Statistical analysis}

The dichotomous outcome variables were disease and symptom status for asthma, hay fever and eczema in the preceeding 12 months. The explanatory variables analysed were those environmental factors reported in the questionnaire: housing factors including the number of people living in the home; country of birth of child; country of birth of mother; and SES. All models were also adjusted for the influence of various potential confounders: age; sex; and school attended.

All variables except age and the number of people living in the home were coded as categorical covariates. Age and the number of people living in the home were analysed as continuous covariates.

Bivariate analysis was performed using Chi-squared tests in the case of pairs of categorical variables or twotailed t-tests in the case of a categorical and a continuous variable. Generalized linear models (logistic regression) [22] were used to model the effects of multiple covariates on the dichotomous outcomes. Both forwards and backwards stepwise modelling procedures were used to select a useful subset of independent predictors of an outcome of interest. The stepwise regression models constructed included the following variables as possible explanatory covariates: Age; sex; birthplace of child (Australia $=1$, other $=0$ ); birthplace of mother (Australia $=1$, other $=0$ ); housing factors; and SES ("disadvantaged"=1, "not disadvantaged" $=0$ ). To investigate any school-specific clustering effects in the data, further models were constructed for each outcome using generalized estimating equations (GEEs) [23] to adjust for any correlations due to the school attended. Minitab for Windows version 12.1 (Minitab, Inc., State College, PA, USA) and S-Plus version 4.5 (Mathsoft, Inc., Cambridge, MA, USA) were used to manage and analyse data. Statistical significance was defined at the standard 5\% level.

\section{Results}

Parental questionnaire responses were obtained for 2,193 children aged $6-7$ yrs in 34 primary schools $(8 \%$ of schools in the sampling area). The response rate was thus $73.6 \%$. Tables 1 and 2 summarize the questionnaire-based variables analysed. The mean age of the study population was $6.5 \mathrm{yrs}$ (SD $0.6 \mathrm{yrs}$ ). The sex ratio was balanced. The mean number of people living in the home was 4.4 (SD $=1.1$ ) and the mean number of bedrooms was 3.7 (SD 0.8). In general, houses were 11-50-yrs-old single-storey free standing dwellings constructed of brick with a concrete floor. The mean number of children ascertained per school was 66.7 (SD 38.2). Missing data were due to either a question not being answered on the questionnaire or, in the case of SES, due to lack of data on a particular school.

For mothers not born in Australia, the UK (16.1\% of all mothers) was the next most common country of birth, followed by New Zealand (3.1\%), Vietnam (2.1\%), Italy $(1.78 \%)$ and the Former Yugoslav Republic (1.05\%). The remaining mothers were born in a variety of countries, each with a frequency of $<1 \%$; the most common countries of birth were in the Western European and Eastern Mediterannean regions. For children not born in Australia, the UK (3.97\% of all children) was also the next most common country of birth, followed by New Zealand (1.32\%). The remaining children were born in a variety of countries, each with a frequency of $<0.5 \%$; the most common countries of birth were in the Western European and Eastern Mediterannean regions.

Australian birth and male sex were both closely associated with a significantly increased risk of asthma in the 
Table 1. - Frequencies of questionnaire-based variables in the study population*

\begin{tabular}{lcc}
\hline & $\begin{array}{c}\text { Frequency } \\
\%(\mathrm{n})\end{array}$ & $\begin{array}{c}\text { Missing data } \\
\%(\mathrm{n})\end{array}$ \\
\hline Asthma in last 12 months & $18.06(396)$ & $0.59(13)$ \\
Wheezing in last 12 months & $22.02(483)$ & $0.59(13)$ \\
Hay fever in last 12 months & $10.44(229)$ & $1.50(33)$ \\
Eczema in last 12 months & $8.80(193)$ & $2.19(48)$ \\
Child born in Australia & $90.06(1975)$ & $0.14(3)$ \\
Mother born in Australia & $62.65(1374)$ & $1.69(37)$ \\
Male sex & $50.25(1102)$ & $0.14(3)$ \\
Attending socioeconomically & $20.38(447)$ & $15.14(332)$ \\
"disadvantaged" school & & \\
Type of home & & $4.01(88)$ \\
Multiunit block & $0.68(15)$ & \\
Two-storey & $5.29(116)$ & \\
One-storey & $28.45(624)$ & \\
Freestanding & $59.83(1312)$ & \\
With common walls & $1.73(38)$ & \\
Building material of home & & $4.06(89)$ \\
Brick/concrete & $90.20(1978)$ & \\
Wood & $3.24(71)$ & \\
Fibroconcrete & $2.51(55)$ & \\
Floor construction & & $6.25(137)$ \\
Concrete slab & $75.24(1650)$ & \\
Wood on pillars & $18.51(406)$ & \\
Age of home yrs & & \\
$<2$ & $8.30(182)$ & \\
2-10 & $36.11(792)$ & \\
$11-50$ & $44.41(974)$ & \\
$51-100$ & $6.48(142)$ & \\
Older & $0.14(3)$ & \\
\hline
\end{tabular}

*: percentage of all subjects with questionnaire data $(n=2,193)$

preceeding 12 months in the index child (tables 3 and 4). Increasing numbers of people living in the home were associated with a significant multiplicative decrease in the risk of asthma in the preceeding 12 months.

Increased risk of hay fever in the last 12 months was significantly associated only with having a mother born in Australia independently of the other possible covariates (tables 3 and 4).

Female sex was closely associated with an increased risk of eczema in the preceeding 12 months in the index child (tables 3 and 4). Although there was a nonsignificant trend to decreased eczema with either no floor coverings or mats on more than half of the floor in the "main bedroom" of the house, the presence of mats on less than half of the floor in the main bedroom was associated with a significantly (3.5-fold) increased risk of eczema in the last 12 months relative to wall-to-wall carpet. Multivariate modelling suggested that houses constructed of fibrocement (a mixture of cement and either asbestos (for houses older than 15 yrs) or fibreglass) were associated with an approximately 2.4 fold increased risk of eczema in the preceeding 12 months relative to houses made of brick or concrete (table 4). As for asthma in the last 12 months, increasing numbers of people living in the home were associated with a significant multiplicative decrease in the risk of eczema in the preceeding 12 months (tables 3 and 4).

All reported associations of response variables with explanatory covariates were independent of the other possible covariates; none of the other variables investigated showed evidence of significant association with current asthma, hay fever or eczema status. Extended modelling using GEEs indicated no substantial clustering effects by school for any of the outcomes investigated (data not shown).

\section{Discussion}

This study was designed to assess the relationship between parent-reported current symptomatic asthma, hay fever and eczema and various environmental factors, and used a representative sample of schoolchildren in the 6-7 yr-old age group from a defined geographical area. The results suggested that household-and country-specific environmental factors are significantly associated with symptomatic asthma and other atopic disease in 6-7-yr-old Western Australian schoolchildren.

The prevalence of asthma, eczema and hay fever symptoms in the preceding 12 months was similar to that found in similarly aged Australian population-based samples using the ISAAC phase 1 core questions $[8,24]$. The prevalence of eczema and hay fever in the preceding 12 months was higher in Perth than those found in ISAAC samples from other developed nations, but was similar to those found in ISAAC samples from several other countries in the region $[5,25]$. Country of birth frequencies for both mothers and children were consistent with the results of the 1991 Australian Census [26].

Questionnaire-based analysis is subject to well-known limitations. However, responses to the ISAAC core questions regarding current wheeze and asthma have been shown to correlate well with objective physiological measures of bronchial hyperresponsiveness in the 7-yr-old age group [24].

The current study investigated schoolchildren aged 6-7 yrs. Diagnosis of clinical asthma and hay fever is generally difficult early in life, but becomes more reliable by school age ( 4-6 yrs). Evidence from longitudinal cohort studies suggests that it is more difficult to define asthma in wheezy infants and children before that age [27].

No evidence was found for clustering in the data due to the school attended. A limitation of this study was that information on environmental tobacco smoke exposure was not evaluated in the ISAAC protocol. However, the lack of significant association between SES, which is

Table 2. - Frequencies of household floor coverings in the study population*

\begin{tabular}{lcccc}
\hline & $\begin{array}{c}\text { Child's bedroom } \\
\%(\mathrm{n})\end{array}$ & $\begin{array}{c}\text { Main bedroom } \\
\%(\mathrm{n})\end{array}$ & $\begin{array}{c}\text { TV/family room } \\
\%(\mathrm{n})\end{array}$ & $\begin{array}{c}\text { Lounge } \\
\%(\mathrm{n})\end{array}$ \\
\hline Wall-to-wall or seagrass carpet & $5.97(131)$ & $83.67(1835)$ & $33.06(725)$ & $10.40(228)$ \\
No carpets/mats, polished wood or cork/vinyl/tiles/linoleum & $83.99(1842)$ & $7.2(159)$ & $44.73(981)$ & $76.33(1674)$ \\
Mats or more than half of the floor & $3.10(68)$ & $2.60(57)$ & $4.88(107)$ & $5.11(112)$ \\
Mats on less than half of the floor & $2.42(53)$ & $1.64(36)$ & $8.30(182)$ & $3.05(67)$ \\
\hline
\end{tabular}

\footnotetext{
*: percentage of all subjects with questionnaire data $(n=2,193)$. TV: television.
} 
Table 3. - Bivariate associations of atopic disease with environmental factors

\begin{tabular}{|c|c|c|c|c|c|c|}
\hline & \multicolumn{2}{|c|}{ Asthma in last 12 months $\left(\chi^{2}{ }_{1}\right)$} & \multicolumn{2}{|c|}{ Hay fever in last 12 months } & \multicolumn{2}{|c|}{ Eczema in last 12 months } \\
\hline & Test statistic* & p-value & Test statistic* & $\mathrm{p}$-value & Test statistic* & p-value \\
\hline Child born in Australia & $14.05\left(\chi_{1}^{2}\right)$ & $<0.001$ & $7.98\left(\chi_{1}^{2}\right)$ & 0.005 & $0.84\left(\chi_{1}^{2}\right)$ & 0.36 \\
\hline Mother born in Australia & $2.97\left(\chi_{1}^{2}\right)$ & 0.08 & $6.10\left(\chi^{2}{ }_{1}\right)$ & 0.01 & $0.44\left(\chi_{1}^{2}\right)$ & 0.51 \\
\hline Sex & $10.84\left(\chi^{2}\right)$ & 0.001 & $1.03\left(\chi_{1}^{2}\right)$ & 0.31 & $6.72\left(\chi^{2}{ }_{1}\right)$ & 0.01 \\
\hline Age & $0.15\left(t_{631}\right)$ & 0.88 & $0.74\left(\mathrm{t}_{309}\right)$ & 0.46 & $1.28\left(\mathrm{t}_{241}\right)$ & 0.20 \\
\hline SES & $1.61\left(\chi_{1}^{2}\right)$ & 0.20 & $1.55\left(\chi_{1}^{2}\right)$ & 0.21 & $0.002\left(\chi_{1}^{2}\right)$ & 0.96 \\
\hline Type of home & $7.43\left(\chi_{4}^{2}\right)$ & 0.12 & $3.52\left(\chi_{4}^{2}\right)$ & 0.48 & $2.56\left(\chi_{4}^{2}\right)$ & 0.64 \\
\hline Building material of house & $2.52\left(\chi_{3}^{2}\right)$ & 0.47 & $4.66\left(\chi_{3}^{2}\right)$ & 0.20 & $6.93\left(\chi_{3}^{2}\right)$ & 0.07 \\
\hline Floor construction & $0.01\left(\chi_{1}^{2}\right)$ & 0.91 & $<0.001\left(\chi_{1}^{2}\right)$ & 0.98 & $2.53\left(\chi_{1}^{2}\right)$ & 0.11 \\
\hline Age of home & $0.06\left(\mathrm{t}_{656}\right)$ & 0.95 & $0.53\left(\mathrm{t}_{296}\right)$ & 0.59 & $1.84\left(\mathrm{t}_{232}\right)$ & 0.07 \\
\hline Number of bedrooms & $1.08\left(\mathrm{t}_{622}\right)$ & 0.28 & $0.08\left(t_{290}\right)$ & 0.93 & $1.16\left(\mathrm{t}_{234}\right)$ & 0.25 \\
\hline $\begin{array}{l}\text { Number of people usually } \\
\text { living in home }\end{array}$ & $2.31\left(\mathrm{t}_{615}\right)$ & 0.02 & $0.79\left(\mathrm{t}_{302}\right)$ & 0.43 & $2.70\left(\mathrm{t}_{238}\right)$ & 0.007 \\
\hline \multicolumn{7}{|l|}{ Floor coverings } \\
\hline Main bedroom & $1.34\left(\chi_{3}^{2}\right)$ & 0.72 & $4.97\left(\chi_{3}^{2}\right)$ & 0.17 & $10.57\left(\chi_{3}^{2}\right)$ & 0.01 \\
\hline Child's bedroom & $1.60\left(\chi_{3}^{2}\right)$ & 0.66 & $3.89\left(\chi_{3}^{2}\right)$ & 0.27 & $0.15\left(\chi_{3}^{2}\right)$ & 0.98 \\
\hline Lounge & $3.51\left(\chi_{3}^{2}\right)$ & 0.32 & $1.98\left(\chi_{3}^{2}\right)$ & 0.58 & $4.62\left(\chi_{3}^{2}\right)$ & 0.20 \\
\hline TV/family room & $6.03\left(\chi_{3}^{2}\right)$ & 0.11 & $5.67\left(\chi_{3}^{2}\right)$ & 0.13 & $4.69\left(\chi_{3}^{2}\right)$ & 0.20 \\
\hline
\end{tabular}

*: Chi-squared or two-tailed t-tests. SES: socioeconomic status; TV: television.

highly correlated with smoking habits in the Australian population [28], and any of the outcomes of interest suggests that passive environmental tobacco smoke exposure was unlikely to have been an important confounding factor in the study population.

\section{Country-specific factors}

The country-of-origin effects suggest that environmental factors associated with being born in Australia have a significant impact upon the risk of developing atopic disease by school age. Studies from countries such as Papua New Guinea, former East Germany and China suggest that "Westernization" is an important risk factor for the development and increased prevalence of atopic asthma $[4,14$, 29]. The present finding that Australian birth was the most significant independent risk factor for current asthma in 67 yr-old children in Perth was consistent with these observations. The country of birth of the index child was associated with an increased risk of asthma, but not of hay fever or eczema. Consistent with recent studies from for- mer East Germany [30], this suggests that country-specific environmental factors present from early in life are more important in the pathogenesis of asthma than that of hay fever or eczema.

Consistent with the present results, studies of immigrants from lesser-developed countries to developed nations such as Australia [19] have also shown a country-specific environmental effect; the first generation offspring of migrants have the same asthma prevalence as children born to nonmigrants in the developed nation. In the present study, maternal country of origin was the only independent predictor of hay fever risk in the preceding 12 months. This may reflect a duration-of-exposure effect, as previous work has shown that hay fever prevalence increases amongst migrants with increasing length of residence in Australia [19].

The nature of important country-specific environmental lifestyle factors remains largely unknown, although physical and mental health practices related to a "healthy" lifestyle [31] have been suggested as possibly affecting

Table 4. - Associations of atopic disease with environmental factors. Final models from multivariate logistic regressions

\begin{tabular}{|c|c|c|c|}
\hline & Explanatory covariates & OR $(95 \% \mathrm{CI})$ & p-value \\
\hline \multirow[t]{3}{*}{ Asthma in last 12 months } & Child born in Australia & $2.37(1.45-3.88)$ & 0.001 \\
\hline & Male sex & $1.45(1.15-1.83)$ & 0.002 \\
\hline & Number of people living in home & 0.88 per person $(0.79-0.99)$ & 0.03 \\
\hline Hay fever in last 12 months & Mother born in Australia & $1.56(1.14-2.12)$ & 0.005 \\
\hline \multirow[t]{11}{*}{ Eczema in last 12 months } & Female sex & $1.49(1.09-2.04)$ & 0.01 \\
\hline & Number of people living in home & 0.82 per person $(0.71$ to 0.96$)$ & 0.01 \\
\hline & Floor covering in main bedroom & & \\
\hline & Wall-to-wall carpet & 1.00 & Reference \\
\hline & No covering & $0.78(0.41-1.49)$ & 0.45 \\
\hline & Mats on $>50 \%$ of floor & $0.54(0.17-1.77)$ & 0.31 \\
\hline & Mats on $<50 \%$ of floor & $3.50(1.52-8.05)$ & 0.003 \\
\hline & Building material of house & & \\
\hline & Brick/concrete & 1.00 & Reference \\
\hline & Wood & $1.05(0.44-2.54)$ & 0.91 \\
\hline & Fibrocement & $2.40(1.17-4.93)$ & 0.02 \\
\hline
\end{tabular}

OR: odds ratio; CI: confidence interval. 
asthma prevalence in developed nations. Data on duration of residence in Australia was not available in this study. However, the association of current atopic disease with Australian birth relative to birth in other countries might be due to an increased awareness of asthma and other atopic disease in the Australian community, different treatment patterns, cultural differences or increased exposures to allergens. Although there has been some evidence that SES is associated with altered asthma and eczema risk [4, 32], the present study was consistent with other studies showing no significant association of SES and atopic disease [33]. However, the current study was limited due to the assignment of SES categorization at a school level rather than an individual level. This may have resulted in the misclassification of some children.

\section{Household-specific factors}

Associations between housing factors and both allergen exposure and atopic symptoms, including eczema, have been previously reported [34, 35]. Household-specific lifestyle factors related to "Westernization" may include decreasing family size, improved hygiene and the concomitant reduction in exposure to viral infections in infancy.

Several studies have now shown that larger sibships are associated with a lower risk of asthma, hay fever and eczema, suggesting a protective effect of number of children sharing an environment at a young age [20, 36-38]. The present results are consistent with these studies and show for the first time in Australian children a multiplicative decrease in the risk of asthma and eczema in the index child in the preceding 12 months for every additional person living in the home. The results suggest that one or more environmental exposures related to family size act to protect children from the development of atopic disease by school age. Factors related to family size which might explain this effect include exposure to viral infections in early childhood $[37,39,40]$ and nutritional factors [20].

Exposure and sensitization to common inhalant aeroallergens, particularly in early life, may be an important environmental factor in the pathogenesis of atopy and asthmatic symptoms [14, 41, 42]. Although this area of research is controversial, some studies have suggested that reducing antigen load (allergen avoidance) may reduce the clinical symptoms of atopy and asthma and risk of specific sensitization [43, 44]. The most common and possibly important indoor inhaled allergen associated with asthma in coastal regions is house dust mite (HDM) [45]. Changes in housing leading to increased exposure and sensitization to inhalant allergens in the developed nations during the period 1940-1970 may have contributed to the increasing asthma, hay fever and eczema incidence and morbidity rates in countries such as Australia [43, 46]. The present study is one of few to investigate the relationship of atopic disease to house-specific factors such as house type, construction and age in 6-7-yr-old schoolchildren. With the exception of eczema risk, none of the physical housing factors investigated showed significant relationships to risk of current atopic disease. Possible explanations for the increased prevalence of current eczema associated with fibrocement houses relative to those constructed primarily of brick/concrete or wood include: the presence of an environmental irritant released by the material; the different efficacy of fibrocement as an insulating agent relative to brick/concrete or wood; and the possible association of this type of housing with (unmeasured) confounding factors. Previous studies have suggested that an important factor in determining mite antigen density and risk of atopy in children is house dampness [34, 47]. It is possible that fibrocement houses are associated with increased risks of house dampness and higher indoor humidity than houses constructed of alternative building materials.

The findings relating to floor coverings were not consistent with a significant effect on current asthma or hay fever risk from HDM exposure associated with the presence of carpets or mats in various rooms of a household. The findings relating to floor coverings and eczema risk suggest that there was a significantly increased prevalence of eczema in those with mats on $<50 \%$ of the floor relative to those with wall-to-wall carpeting in the "main bedroom" of the house; this might suggest that parents of children with current eczema are taking some allergen-avoidance measures in this population. A related factor may be that children still suffering from eczema at school age are likely to have more severe disease than those who had eczema only in infancy. However, this explanation is complicated by the finding that children with either no floor covering or mats on $>50 \%$ of the floor relative to those with wall-towall carpeting in the "main bedroom" of the house had a trend towards decreased prevalence of eczema (although these differences were not significant).

Data on the temporal relationship of the housing factors studied and atopy symptoms were not available. It is therefore impossible to state with certainty that these housing factors preceded the disease. However, the number of people living in the house is likely to have remained moreor-less constant for much of the index child's life, and hence this housing factor is likely to have preceded or coexisted with the atopic disease. The housing factors investigated in the current study may or may not have contributed to the development of atopic disease; their cross-sectional associations may however also reflect a potential role as factors which exacerbate or modify existing atopic disease. Another possible interpretation of the present findings could be that they are due to reverse causality, i.e. parents of atopic children might avoid certain types of housing or take allergen avoidance measures within a house. However, in the case of house construction, it seems implausible that parents of such children would avoid houses constructed of brick and concrete in favour of houses constructed of fibrocement.

\section{Sex}

Consistent with the present results, male sex has been consistently associated with increased risk of current asthma in children $[42,48]$. The present results regarding sex and eczema were also consistent with a previous large study of 7-yr-old children, which showed an increased risk of eczema in females [49]. These findings may be due to intrinsic differences, possibly genetic, between male and female children, or may be secondary to socioenvironmental differences associated with sex, such as the different parental perception of males and females. Such secondary differences might lead to sexdependent diagnosis and/or treatment of asthma and other atopic disease [50]. 


\section{Conclusions}

This cross-sectional study suggests that household and country-specific environmental factors are associated with asthma, hay fever and eczema risk in 6-7-yr-old schoolchildren in Perth, and that some of these factors may have contributed to the increased prevalence of these diseases in Australia. The definition of potentially preventable environmental factors affecting risk of atopic disease is important given the apparent world-wide increases in the prevalence of childhood atopic disease [5, 12]. This study identifies building, furnishing and lifestyle factors which are associated with an altered prevalence of atopic disease. Prevention may need to address both the removal or minimization of potential allergens and pollutants in the house and changes in lifestyle factors which will lead to immunological tolerance rather than sensitization in highrisk groups within the Australian community.

\section{Appendix: Definition of questionnaire-defined symp- tom-based outcomes}

\begin{tabular}{|c|c|}
\hline Outcome & Questions (positive responses) \\
\hline \multirow{3}{*}{$\begin{array}{l}\text { Asthma in last } \\
12 \text { months }\end{array}$} & "Has your child ever had asthma?" \\
\hline & and \\
\hline & $\begin{array}{l}\text { "Has your child had wheezing and } \\
\text { whistling in the chest in the last } \\
12 \text { months?" }\end{array}$ \\
\hline \multirow{5}{*}{$\begin{array}{l}\text { Hay fever in last } \\
12 \text { months }\end{array}$} & "Has your child ever had hayfever?" \\
\hline & and \\
\hline & $\begin{array}{l}\text { "In the past } 12 \text { months, has your child had } \\
\text { a problem with sneezing or a runny or } \\
\text { blocked nose when he/she DID NOT } \\
\text { have a cold or the flu?" }\end{array}$ \\
\hline & and \\
\hline & $\begin{array}{l}\text { "In the past } 12 \text { months, has this nose } \\
\text { problem been accompanied by } \\
\text { itchy-watery eyes?" }\end{array}$ \\
\hline \multirow{3}{*}{$\begin{array}{l}\text { Eczema in last } \\
12 \text { months }\end{array}$} & "Has your child ever had eczema?" \\
\hline & and \\
\hline & $\begin{array}{l}\text { "Has your child had an itchy rash which } \\
\text { was coming and going for at least } 6 \\
\text { months at any time in the last } 12 \\
\text { months?" }\end{array}$ \\
\hline
\end{tabular}

Acknowledgements. The authors thank the children and parents who participated in this study.

\section{References}

1. Sears MR, Burrows B, Flannery EM, Herbison GP, Hewitt CJ, Holdaway MD. Relation between airway responsiveness and serum $\operatorname{IgE}$ in children with asthma and in apparently normal children. $N$ Engl $J$ Med 1991; 325: 1067-1071.

2. Burrows B, Martinez F, Halonen M, Barbee R, Cline M. Association of asthma with serum IgE levels and skin-test reactivity to allergens. $N$ Engl J Med 1989; 320: 271-277.

3. Cline M, Burrows B. Distribution of allergy in a population sample residing in Tuscon, Arizona. Thorax 1989; 44: 425-431.

4. von Mutius E, Martinez FD, Fritzsch C, Nicolai T, Roell
G, Thiemann HH. Prevalence of asthma and atopy in two areas of West and East Germany. Am J Respir Crit Care Med 1994; 149(2 Pt 1): 358-364.

5. Committee TISoAaAiCIS. Worldwide variation in prevalence of symptoms of asthma, allergic rhinoconjunctivitis, and atopic eczema: ISAAC. Lancet 1998; 351: 12251232.

6. Janson C, Chinn S, Jarvis D, Burney P. Physician diagnosed asthma and drug utilization in the European Community Health Survey. Eur Respir J 1997; 10: 1795-1802.

7. Woolcock A, Peat J, Salome C. Prevalence of bronchial hyperresponsiveness and asthma in a rural adult population. Thorax 1987; 42: 38-44.

8. Robertson C, Dalton M, Peat J, et al. Asthma and other atopic diseases in Australian children. Med J Aust 1998; 168: 434-438.

9. Toelle B, Peat J, Mellis C, Woolcock A. The cost of childhood asthma to Australian families. Pediatr Pulmonol 1995; 19: 330-335.

10. Burney PGJ, Chinn S, Rona RJ. Has the prevalence of asthma increased in children? Evidence from the national study of health and growth 1973-86. BMJ 1990; 300: 1306-1310.

11. Peat JK, Berg RHvd, Green WF, Mellis CM, Leeder SR, Woolcock AJ. Changing prevalence of asthma in Australian children. Br Med J 1994; 308: 1591-1596.

12. Asher MI, Keil U, Anderson HR, et al. International Study of Asthma and Allergies in Childhood (ISAAC): rationale and methods. Eur Respir $J$ 1995; 8: 483-491.

13. Arshad SH, Stevens M, Hide DW. The effect of genetic and environmental factors on the prevalence of allergic disorders at the age of two years. Clin Exp Allergy 1993; 23: 504-511.

14. Björkstén B. Risk factors in early childhood for the development of atopic diseases. Allergy 1994; 49: 400-407.

15. Sandford A, Weir T, Pare P. The genetics of asthma. Am J Respir Crit Care Med 1996; 153: 1749-1765.

16. Hopper J, Jenkins M, Carlin J, Giles G. Increase in the self-reported prevalence of asthma and hay fever in adults over the last generation: a matched parent-offspring study. Aust J Public Health 1995; 19: 120-124.

17. Hopkin J. Genetics of atopy. Pediatr Allergy Immunol 1995; 6: 139-144.

18. Mellis C, Peat J, Bauman A, Woolcock A. The cost of asthma in New South Wales. Med J Aust 1991; 155: 522_528.

19. Leung RC, Carlin JB, Burdon JG, Czarny D. Asthma, allergy and atopy in Asian immigrants in Melbourne. Med $J$ Aust 1994; 161: 418-425.

20. Rona R, Duran-Tauleria E, Chinn S. Family size, atopic disorders in parents, asthma in children, and ethnicity. $J$ Allergy Clin Immunol 1997; 99: 454-460.

21. Zubrick S, Silburn S, Gurrin L, et al. Western Australian Child Health Survey: Education, Health and Competence. Perth, Australian Bureau of Statistics/TVW Telethon Institute for Child Health Research, 1997.

22. Armitage P, Berry G. Statistical methods in medical research. 3rd ed. Oxford, Blackwell Scientific Publications, 1994.

23. Burton P, Gurrin L, Sly P. Extending the simple linear regression model to account for correlated responses: an introduction to generalized estimating equations and multi-level mixed modelling. Stat Med 1998; 17: 1261-1291.

24. Ponsonby A-L, Couper D, Dwyer T, Carmichael A, Wood-Baker R. Exercise-induced bronchial hyperresponsiveness and parental ISAAC questionnaire responses. Eur Respir J 1996; 9: 1356-1362. 
25. Strachan DP, Sibbald B, Weiland SK, et al. Worldwide Variations in Prevalence of Symptoms of Allergic Rhinoconjunctivitis in Children - the International Study of Asthma and Allergies in Childhood (Isaac). Pediatr Allergy Immunol 1997; 8: 161-176.

26. Australian Bureau of Statistics. 1991 Census: Australia in Profile. Report No 2821.0. Canberra, 1992.

27. Martinez FD, Wright AL, Taussig LM, et al. Asthma and wheezing in the first six years of life. $N$ Engl Med 1995; 332: 133-138.

28. Lange K, Westlake J, Spence MA. Extensions to pedigree analysis III. Variance components by the scoring method. Ann Hum Genet 1976; 39: 485-491.

29. Leung R, Jenkins M. Asthma, allergy and atopy in southern Chinese school students. Clin Exp Allergy 1994; 24: 353-358.

30. von Mutius E, Weiland SK, Fritzsch C, Duhme H, Keil U. Increasing prevalence of hay fever and atopy among children in Leipzig, East Germany. Lancet 1998; 35: 862 866.

31. Shirakawa T, Hayakawa $\mathrm{K}$, Shimizu $\mathrm{T}$, Morimoto $\mathrm{K}$. Association of life style with high risk of hyperimmunity and of immunosuppression mediated by age. J Clin Epidemiol 1996; 49: 1059-1065.

32. Crockett AJ, Alpers JH. A profile of respiratory symptoms in urban and rural South Australian schoolchildren. J Paediatr Child Health 1992; 28: 36-42.

33. Gergen P. Social class and asthma-distinguishing between the disease and the diagnosis [editorial; comment]. Am J Public Health 1996; 86: 1361-1362.

34. Garrett MH, Rayment PR, Hooper MA, Abramson MJ, Hooper BM. Indoor airborne fungal spores, house dampness and associations with environmental factors and respiratory health in children. Clin Exp Allergy 1998; 28: 459-467.

35. Ronmark E, Lundback B, Jonsson E, Platts-Mills T. Asthma, type-1 allergy and related conditions in 7- and 8yr-old children in northern Sweden: prevalence rates and risk factor pattern. Respir Med 1998; 92: 316-324.

36. Golding J, Peters T. Eczema and fever. In: Butler N, Golding J, eds. From birth to five. A study of the health and behaviour of Britain's five year-olds. Oxford: Pergamon, 1986; 171-186.

37. Strachan D. Hay fever, hygiene, and household size. BMJ 1989; 299: 1259-1260.

38. Crane J, Pearce N, Shaw R, Fitzharris P, Mayes C. Asthma and having siblings [letter]. BMJ 1994; 309: 272.

39. Martinez F. Role of viral infections in the inception of asthma and allergies during childhood: could they be protective? Thorax 1994; 49: 1189-1191.

40. Grange JM, Stanford JL, Rook GA, Wright P. Role of viral infections in the inception of childhood asthma and allergies. Thorax 1995; 50: 701.

41. Sporik R, Chapman MD, Platts-Mills TA. House dust mite exposure as a cause of asthma. Clin Exp Allergy 1992; 22: 897-906.

42. Sears MR, Burrows B, Flannery EM, Herbison GP, Holdaways MD. Atopy in Childhood. I. Gender and allergen related risks for development of hay fever and asthma. Clin Exp Allergy 1993; 23: 941-948.

43. Platts-Mills T. The role of indoor allergens in asthma. Allergy 1995; 50 (suppl 22): 5-12.

44. Peroni DG, Boner AL, Vallone G, Antolini I, Warner JO. Effective allergen avoidance at high altitude reduces allergen-induced bronchial hyperresponsiveness. $\mathrm{Am} \mathrm{J}$ Respir Crit Care Med 1994; 149: 1442-1446.

45. Bierman C. Environmental control of asthma. Immunol Allergy Clin North Am 1996; 16: 753-764.

46. Cullinan P, Newman-Taylor AJ. Asthma in children: environmental factors. Br Med $J$ 1994; 308: 1585-1586.

47. Kuehr J, Frischer T, Karmaus W, et al. Natural variation in mite antigen density in house dust and relationship to residential factors. Clin Exp Allergy 1994; 24: 229-237.

48. Clough JB. The effect of gender on the prevalence of atopy and asthma. Clin Exp Allergy 1993; 23: 883-885.

49. Schultz Larsen F, Diepgen T, Svensson A. The occurrence of atopic dermatitis in north Europe: an international questionnaire study. J Am Acad Dermatol 1996; 34: 760764.

50. Kuhni CE, Sennhauser FH. The Yentl syndrome in childhood asthma: risk factors for undertreatment in Swiss children. Pediatr Pulmonol 1995; 19: 156-160. 